\title{
Screening of Coriander Genotypes for their Relative Susceptibility against Aphids under Field Conditions
}

\author{
Meena N.K.*, Lal G., Meena S.S., Kant K. and Meena R.D. \\ ICAR-National Research Centre on Seed Spices, Ajmer (Rajasthan), India \\ * Corresponding author email: email: narottammeena@gmail.com
}

ABSTRACT

The field experiments were conducted during Rabi 2013-14 and 2014-15 to screen out twelve varieties/entries of coriander (Coriandrum sativum L.) for their relative susceptibility against aphids. None of the varieties/entries escaped the infestation of aphids. The build-up of aphid infestation started from second half of December and reached to its maximum in the first to third week of February in both years and then gradually declined. On the basis of grade index of mean aphid population, coriander varieties $\mathrm{RCr}$ 684 (25.45 aphids/plant), RCr-446 (26.45 aphids/plant), ACr-1 (26.60 aphids/plant), RCr436 (41.75 aphids/plant), Gujarat Coriander-2 (42.45 aphids/plant), Pant Haritma (43.50 aphids/plant) and Gujarat Coriander-1 (43.70 aphids/plant) were categorized as least susceptible, Rajendra Swati and RCr-41 were moderately susceptible, whereas, Swati (CS-6), Sadhna (CS-4) and Sindhu (CS-2), 73.88, 70.60 and 69.50 aphids/plant, respectively were categorized as highly susceptible varieties of coriander against aphids under field conditions. Coriander variety $\mathrm{RCr}-684$ received maximum yield (16.82 and $16.63 \mathrm{q} / \mathrm{ha})$ for both the years followed by ACr-1 and RCr-446.

Key words: Aphids, Coriander Genotypes, Semi-arid region and Susceptibility.

\section{INTRODUCTION}

Coriander (Coriandrum sativum L.) is an important major seed spice crop, grown for leaves as well as seed purpose.It belongs to the family Apiaceae, is a native of southern Europe and northern Africa to southwestern Asia. The coriander plants are annual herb, stems erect, branched or bushy, diploid, chromosome number $2 \mathrm{n}=22$. Coriander seeds and leaves contain essential oils, which account for aromatic character of the plant (Sankaracharya and Sankaranarayana, 1989). The seeds have a lemony citrus flavour when crushed, due to the linalool, terpenes, pinene, and limonene, among others (Zheljazkov et al., 2014). Coriander seeds are considered as carminative, diuretic, stomachic, antibilious, refrigerant and aphrodisiac (Butani, 1984).The fresh leaves are an ingredient in many South Asian foods (such as rasams, chutneys, and salads); in Chinese and Thai dishes; in Mexican cooking, particularly in salsa and guacamole and as a garnish; and in salads in Russia and other CIS countries (Moulin, 2002). It is mainly grown in Rajasthan, Madhya Pradesh, Andhra Pradesh, Gujarat and Assam in a large area as majorRabi season crop and cultivated in many more states in large to small areas. Coriander is most susceptible crop to aphids in semi-arid region, if plant protection measures not applied on time; it causes nearly 40-50\% yield losses. In present situation of agriculture, farmers are using a number of pesticides for aphid control resulting development of pest resistance to various commonly used insecticides, pest resurgence, and outbreaks as well as severe mortality of natural enemies and pollinators particularly honeybees, hence the identification of resistance source against aphids is the main factor to manage the pest.

Keeping these in view, field experiment were conducted at research farm, ICAR-National Research Centre on Seed Spices, Ajmer to evaluate twelve varieties/entries of coriander viz., Gujarat Coriander-1, Gujarat Coriander-2, Sadhna (CS-4), ACr-1, Swati (CS-6), RCr-41, RCr-436, RCr-684, Hisar Sugandh, Pant Haritma, Sindhu (CS-2) and Rajendra Swati for their resistance/susceptibility 
against aphids during Rabi 2013-14 and 2014-15 to find out the resistance sources as breeding material against aphids.

\section{MATERIALS AND METHODS}

The field experiments on screening of different varieties/entries of coriander for their relative susceptibility against aphids were conducted at ICARNational Research Centre on Seed Spices, Ajmer for two consecutive years 2013-14 and 2014-15. The study location is lying between $74^{\circ} 35^{\prime} 39^{\prime \prime}$ to $74^{\circ} 36^{\prime}$ $01 "$ E longitude and $26^{\circ} 22^{\prime} 12^{\prime \prime}$ to $26^{\circ} 22^{\prime} 31^{\prime \prime} \mathrm{N}$ latitude at an altitude of $486 \mathrm{~m}$ above mean see level. The region fall under III agro-climatic zone of Rajasthan is considered under semi-arid region. Soil fertility status of institute's experimental field is sandy loam, poor fertility and water holding capacity, having $\mathrm{pH}$ 8-8.3, EC 0.07-0.12 and organic carbon 0.150.23 percent along with available $\mathrm{N} 178.5 \mathrm{~kg} / \mathrm{ha}$ (low), $\mathrm{P}_{2} \mathrm{O}_{5} 12 \mathrm{~kg} /$ ha (Medium), $\mathrm{K}_{2} \mathrm{O} \mathrm{kg} / \mathrm{ha}$ (low). The area receives annual rainfall $250-350 \mathrm{~mm}$ and temperature range $22-36{ }^{\circ} \mathrm{C}$ (maximum) and $5-20{ }^{\circ} \mathrm{C}$ (minimum) with $64-80 \%$ relative humidity during cropping Rabi season.

Twelve varieties/entries i.e. Rajendra Swati, ACr-1, Gujarat Coriander-1, RCr-41, Pant Haritma, RCr-684, Sadhna (CS-4), Swati (CS-6), RCr-446, Sindhu (CS2), Gujarat Coriander-2 and $\mathrm{RCr}-436$ were sown in well prepared and statistically laid out fields in Randomized Block Design concept with 03 replications. The seeds of above varieties/entries were sown in the plot sized of $3 \times 3$ meter, under specified geometry adopted in pop of the institute. Seeds were treated with Trichoderma viride @6g/ $/ \mathrm{kg}$ of seed to avoid the seed borne diseases. Plant protection measures were not applied during standing crop to allow the aphid incidence on the crops. The observations on aphid population were recorded at weekly intervals from five randomly selected and tagged plants/plot. Initially, whole plants were taken in to study and later on it was sifted to $10 \mathrm{~cm}$ twig when crop was in full grown and umbels during flowering and finally it was considered as aphid population per plant. The relative susceptibility was determined on the basis of grade index worked out on peak infestation by using formulae $\mathrm{X}^{-} \pm \sigma\left(\mathrm{X}^{-}\right.$: mean of peak aphid population; $\sigma$ : standard deviation for insect population) as given below, wherein, the incidence was measured on the basis of mean aphid population per plant.

\begin{tabular}{lc}
\hline Grade & $\begin{array}{c}\text { Mean aphid } \\
\text { population/plant }\end{array}$ \\
\hline Least susceptible & $<48.36$ \\
\hline Moderately susceptible & $48.36-66.13$ \\
\hline Highly susceptible & $>66.13$ \\
\hline
\end{tabular}

The data were obtained and transformed in sqrt. $\mathrm{X}+$ 0.5 values and subjected to analysis of variance to find out the critical difference (Gomez and Gomez, 1983).

\section{RESULTS AND DISCUSSION}

Twelve varieties/entries of coriander were screened out for their relative susceptibility to aphids (Hyadaphis coriandri Das and Myzus persicae Sulzer) and the data on mean aphid's mixed population per plant were taken for two consecutive years and presented in Table 1 and 2, revealed that, none of the varieties/entries was free from aphid infestation. Initially, the aphid infestation started in second half of December (35 DAS) with very less in populations in both the years. In 2013-14, the aphid infestation started on second half of December with few aphids per plant on some coriander varieties, whereas $\mathrm{RCr}$ 684, RCr-446 and ACr-1 were remained free from the aphid infestation at this stage. Then after, pest infestation increased gradually and reached to its maximum during February month with three peaks depending upon the varieties/entries (Table 1). The coriander variety $\mathrm{RCr}-684$ received lowest aphid infestation (23.70 aphids/plant) followed by RCr-446 and ACr-1 with 24.10 and 24.20 aphids/plant, respectively. The maximum aphid infestation was observed on variety Swati (CS-6) 71.10 aphids/plant followed by Sadhna (CS-4) Sindhu (CS-2) and RCr41 having aphids population of $66.40,65.00$ and 64.20 aphids/plant, respectively. The remaining varieties/ entries were received the aphid infestation with ranged from 41.70 to 52.30 aphids/plant. Over the season, the lowest mean aphid infestation (9.21 aphids/plant) was recorded on variety $\mathrm{RCr}-684$ followed by ACr-1 and RCr-446, whereas, maximum on Swati (CS-6) and Sadhna (CS-4) and Sindhu (CS$2)$. The highest yield of coriander seed was also recorded from the variety $\mathrm{RCr}-684(16.82 \mathrm{q} / \mathrm{ha})$ followed by ACr-1 (15.74q/ha) and RCr-446 (12.89 $\mathrm{q} /$ ha), while minimum yield $4.14 \mathrm{q} / \mathrm{ha}$ was obtained 


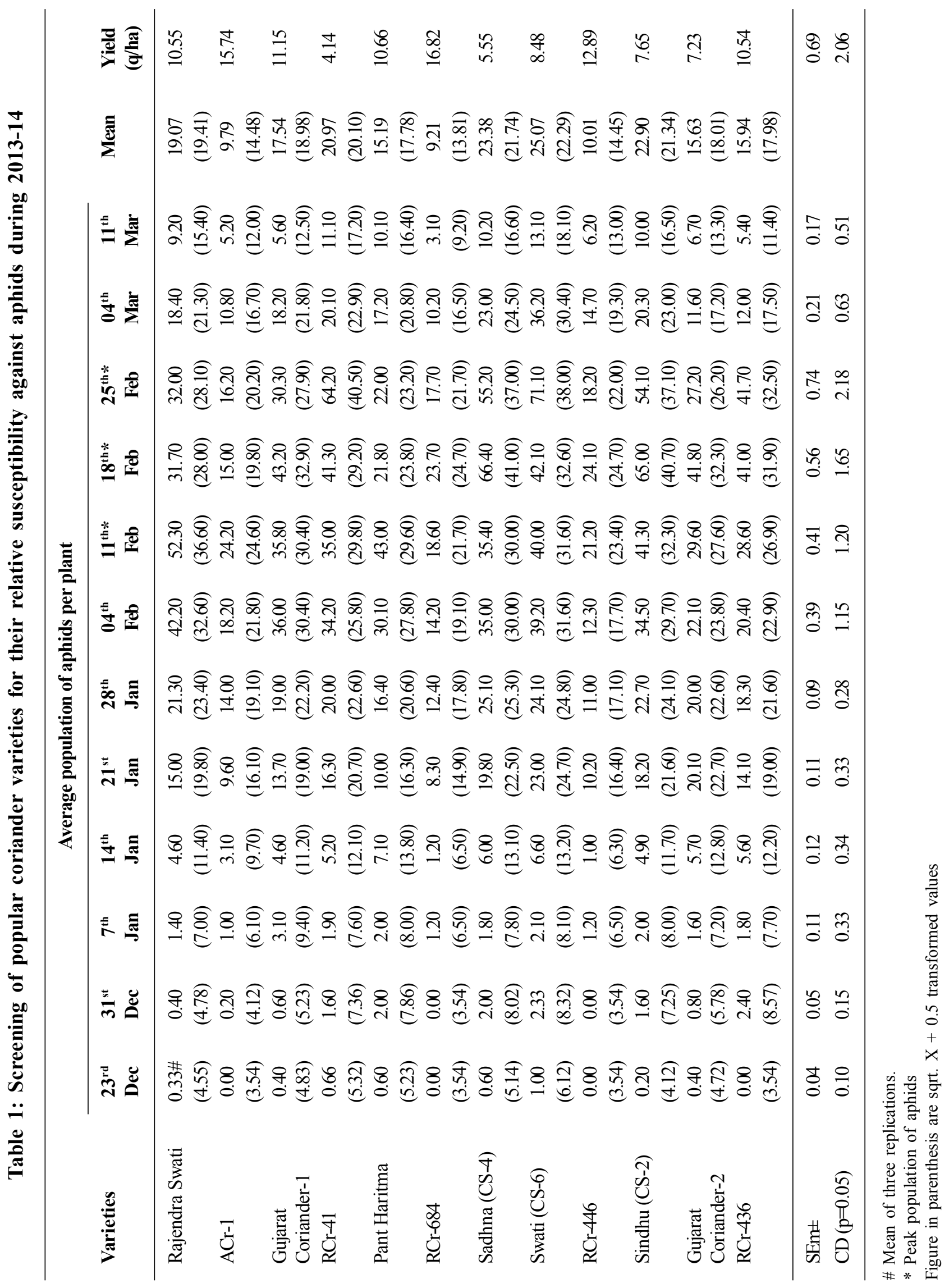




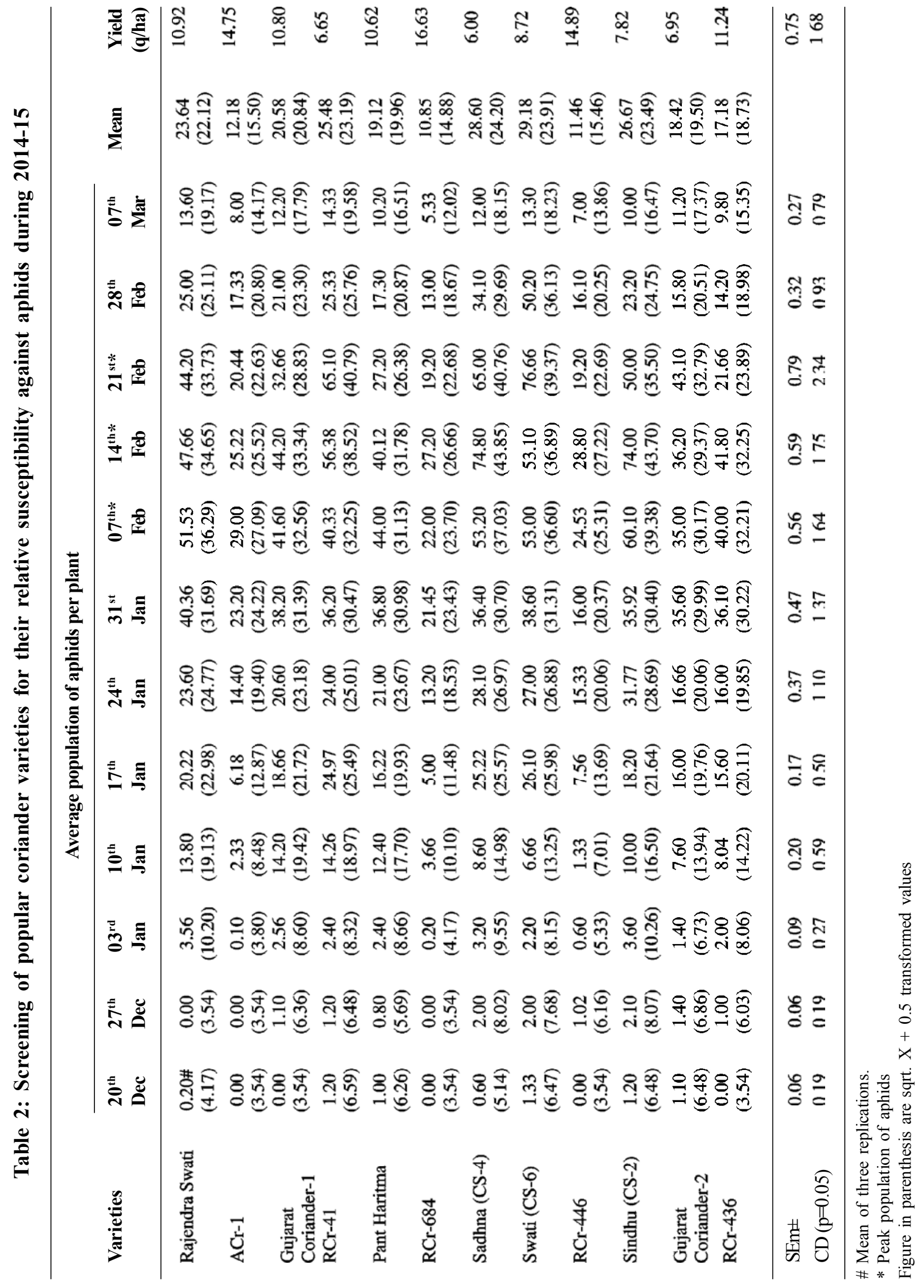


from the variety $\mathrm{RCr}-41$, which was highly susceptible to aphid.

Similarly, in 2014-15 the aphid infestation started in third week of December with few aphids per plant on some coriander varieties, whereas RCr-684, RCr446 and $\mathrm{ACr}-1$ were remained free from the aphid infestation at this stage. Then after pest infestation increased gradually and reached to its maximum during the month of February with three peaks i.e. $7^{\text {th }}$ February (on varieties Rajendra Swati, and Pant Haritma), $14^{\text {th }}$ February (on varieties Gujarat Coriander-1, RCr-684, Sadhna (CS-4), RCr-446,

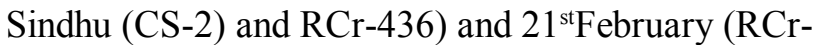
41, Swati (CS-6) and Gujarat Coriander-2) depending upon the varieties/entries (Table 2). The coriander variety $\mathrm{RCr}-684$ received lowest aphid infestation (27.20 aphids/plant) followed by RCr-446 and ACr-1 with 28.80 and 29.00 aphids/plant, respectively. Meenaet al. (2002b) also reported that coriander varieties $\mathrm{RCr}-446$ and $\mathrm{RCr}-436$ were found least susceptible against aphids are in accordance the present finding. These three varieties were found statistically at par for aphid infestation. The maximum aphid infestation was observed on variety Swati (CS6) 76.66 aphids/plant followed by Sadhna (CS-4) Sindhu (CS-2) and RCr-41 having aphids population of $74.80,74.00$ and 65.10 aphids/plant, respectively. The remaining varieties/entries were received the aphid infestation with ranged from 41.80 to 51.33 aphids/plant. The highest yield of coriander seed was recorded from the variety $\mathrm{RCr}-684(16.63 \mathrm{q} / \mathrm{ha})$ followed by RCr-446 (14.89 q/ha) and ACr-1 (14.75q/ ha), while minimum yield $6.00 \mathrm{q} /$ ha was obtained from the variety Sadhna (CS-4) and RCr-41 (6.65q/ha), which were highly susceptible to aphid. Based on two year results, it was evident from the study that the coriander varieties i.e. RCr-684 (25.45 aphids/plant), RCr-446 (26.45 aphids/plant), ACr-1 (26.60 aphids/ plant), RCr-436 (41.75 aphids/plant), Gujarat Coriander-2 (42.45 aphids/plant), Pant Haritma (43.50 aphids/plant) and Gujarat Coriander-1 (43.70 aphids/ plant) are moderately susceptible, whereas, Swati (CS-6), Sadhna (CS-4) and Sindhu (CS-2) with aphid population $73.88,70.60$ and 69.50 aphids/plant, respectively were categorized as highly susceptible varieties of coriander against aphids under field conditions.

\section{REFERENCES}

Butani, D.K. 1984. Spices and pest problems; coriander. Pesticides, 18(9): 15-17.

Gomez, A.K. and Gomez, A.A. (1983). Statistical procedure for agricultural research. $2^{\text {nd }} E d n$. Wiley Interscience Publication, New York, pp 25.

Meena, P.C., Sharma, J.K. and Noor, A. 2002 b. Varietal reaction of coriander Coriandrum sativum L. and impact of date of sowing in incidence of aphid Hyadaphis coriandri Das. Indian Journal of Entomology, 64(1): 58-62.
Moulin, Leo (2002). Eating and Drinking in Europe: A Cultural History. Mercatorfonds. p. 168.

Sankaracharya, N.B. and Sankaranarayana, M.L. 1989. Processing and flavor quality of seed spices. First National Seminar Seed Spices, Jaipur, 24-25 October, pp. 301-328.

Zheljazkov, V. D.; Astatkie, T; Schlegel, V (2014). Hydrodistillation extraction time effect on essential oil yield, composition and bioactivity of coriander oil. Journal of Oleo Science. 63 (9): $857-65$. 